Winter 2008

\title{
A Theory of Open-Source Anarchy
}

David Fidler

Indiana University Maurer School of Law, dfidler@indiana.edu

Follow this and additional works at: https://www.repository.law.indiana.edu/ijgls

Part of the Civil Law Commons, and the International Law Commons

\section{Recommended Citation}

Fidler, David (2008) "A Theory of Open-Source Anarchy," Indiana Journal of Global Legal Studies: Vol. 15 : Iss. 1 , Article 11.

Available at: https://www.repository.law.indiana.edu/ijgls/vol15/iss1/11

This Symposium is brought to you for free and open access by the Law School Journals at Digital Repository @ Maurer Law. It has been accepted for inclusion in Indiana Journal of Global Legal Studies by an authorized editor of Digital Repository @ Maurer Law. For more information, please contact rvaughan@indiana.edu.

\section{$\Psi$}

JEROME HALL LAW LIBRARY

INDIANA UNIVERSITY

Maurer School of Law
Bloomington 


\title{
A Theory of Open-Source Anarchy
}

\author{
David P. FidleR*
}

\begin{abstract}
The rise of the importance of non-State actors in global politics challenges existing theories of international relations, and this article presents a new approach to the nonState actor phenomenon by developing a "theory of open-source anarchy." The article reviews the anarchy problem in the study of international relations and how leading theories explain this problem. This analysis questions whether these leading theories can explain the nature of non-State actor participation in contemporary global affairs. The article then develops a theoretical framework that addresses the non-State actor challenge. The framework argues that the nature of anarchy has shifted from a condition monopolized by States to one in which anarchy has become "open source" and accessible to non-State actors in unprecedented ways. The article explores the relationship between material power and ideas in open-source anarchy to explain the manner in which international relations operate in the early twenty-first century.
\end{abstract}

\section{INTRODUCTION}

Many analyses of the impact of globalization on international relations stress the growing involvement and influence of non-State actors in world affairs. One implication frequently emphasized is the weakening ability of the State to fulfill traditional functions, such as national security and economic stability and prosperity. ${ }^{1}$ The perceived erosion of State capability also adversely affects its ability to

* James Louis Calamaras Professor of Law, Indiana University School of Law-Bloomington, and Director of the Indiana University Center on American and Global Security.

1. Daniel W. Drezner, All Politics Is Global: Explaining International Regulatory REGIMES 4 (2007) (noting that "[m]ost strands of research on this topic share a common assumption-the decline of state autonomy relative to other factors and actors.").

Indiana Journal of Global Legal Studies Vol. 15 \#1 (Winter 2008)

CIndiana University School of Law 
produce other important public goods, including the regulation of domestic markets, provision of health care, and prevention of environmental degradation. The perceived rise of non-State actors as players in world politics has many consequences that require further theoretical analysis and demand policy attention because the importance of this rise remains hotly contested. Without minimizing the significance of addressing real-world problems, this article explores theoretical aspects of the purported emergence of non-State actors as more serious factors in international relations.

The idea that non-State actors can have significant impact in world affairs connects to long-standing debates in international relations theory about how such actors relate to the structure and dynamics of the international system. As examined below, theories that emphasize the centrality of the State have little tolerance for arguments that non-State actors are reshaping the nature of international relations. Theories that build non-State actors into their explanations are interested in how non-State actors influence politics nationally and internationally. These theories tend to view this influence operating within the process of State preference formation or the world of ideas as opposed to the world of material power. None of the leading theories of international relations adequately captures, however, what is happening with the rise of non-State actors in world politics, particularly the growing ability of these actors to exercise material capabilities vis-à-vis States and each other, and the resulting impact of this ability on how ideas play a role in international relations. As a result, this article attempts to sketch a theory of what I call "open-source anarchy."

One of the most important concepts in international relations theory is "anarchy." In fact, international relations theory contains diverse attempts to come to grips with the problem and potential of anarchy as the environment in which States and non-State actors interact. Two leading theories, realism ${ }^{3}$ and institutionalism, ${ }^{4}$ explain anarchy by focusing on the interactions of States, and

2. See, e.g., Kenneth N. Waltz, Realist Thought and Neorealist Theory, reprinted in CoNTroversies In International Relations Theory 67, 80 (C. W. Kegley, Jr. ed., 1995).

3. On realism as a theory of international relations, see generally Edward H. Carr, The Twenty Years' Crisis, I919-1939: An Introduction to the Study of International Relations (1939); Hans J. Morgenthau, Politics Among Nations: The Struggle for Power and Peace (5th ed. rev. 1978); Michael J. Smith, Realist Thought From Weber to Kissinger (1986); Kenneth N. Waltz, Theory of International Politics (1979); and Tim Dunne \& Brian C. Schmidt, Realism, in The Globalization of World Politics, 141 (John Baylis \& Steve Smith, eds., 2d ed. 2001).

4. On institutionalism as a theory of international relations, see generally Robert O. Keohane, After Hegemony: Cooperation and Discord in the World Political Economy (1984); Stephen D. Krasner, International Regimes (1983); Robert O. Keohane, International Institutions: 
these theories discount or dismiss non-State actors as factors in State-centric anarchical politics. Other theories, namely liberalism ${ }^{5}$ and constructivism, ${ }^{6}$ create space for non-State actors to influence anarchical politics. This article's interest in a theory of open-source anarchy arises from the concern that these established approaches do not reflect how non-State actors fit into the structure and dynamics of anarchy in the early twenty-first century. Contemporary anarchy has features that echo aspects of these theoretical perspectives, but those features also have qualities that escape the explanatory power of these perspectives.

Theoretically, we need to explain how non-State actors wield independent, material power that not only challenges States but also transforms the anarchy that continues to characterize politics among nations. Realism and institutionalism analyze how State pursuit and use of material power affects anarchy, but these theories cannot accommodate non-State actors exercising power through independent material capabilities. Similarly, although liberalism and constructivism build non-State actors into their explanations of anarchy, these theories connect non-State actor involvement with State-preference formation and the world of ideas rather than with the direct exercise of material power. The theory of opensource anarchy attempts to explain how and why anarchy today reflects the ability of many non-State actors to develop and use independent material power in ways that affect world politics. As explored below, anarchy is undergoing a transformation that presents States and non-State actors with unprecedented governance challenges for which traditional approaches prove inadequate. Therefore, the emergence of open-source anarchy has sobering portents for international relations in the twenty-first century.

Two Approaches, 32 Int'L Stud. Q. 379, 384 (1988); Robert O. Keohane \& Lisa Martin, The Promise of Institutional Theory, 20 INT'L Security 39 (1995).

5. On liberalism as a theory of international relations, see generally Michael W. Doyle, Liberalism and World Politics, 80 Am. Pol. Scr. Rev. 1151 (1986); Michael W. Doyle, Liberalism and World Politics Revisited, in Controversies in International Relations Theory, supra note 2, at 83; Tim Dunne, Liberalism, in The Globalization of World Politics, supra note 3, at 162; Andrew Moravcsik, Taking Preferences Seriously: A Liberal Theory of International Politics, 51 INT'L ORG. 513 (1997).

6. See Alexander Wendt, Social Theory of International Politics (1999); Jeffrey T. Checkel, The Constructivist Turn in International Relations Theory, 50 World Pol. 324 (1998); John G. Ruggie, What Makes the World Hang Together? Neo-Utilitarianism and the Social Constructivist Challenge, 52 Int'L OrG. 855(1998); Steve Smith, Reflectivist and Constructivist Approaches to International Theory, in The Globalization of World Politics, supra note 3, at 234-49; Alexander Wendt, Anarchy is What States Make of It: The Social Construction of Power Politics, 46 InT'L Org. 391 (1992). 


\section{The Anarchy Problem in International Relations}

\section{A. Anarchy: Technical Meaning and Theoretical Aspects}

For students of international relations, anarchy has a specific technical meaning, which often surprises those not familiar with this discipline. Most people associate anarchy with disorder and chaos, but international relations theorists do not think of anarchy in this way. For them, anarchy describes a context in which actors in a political system recognize no common, superior authority. ${ }^{7}$ Anarchy is the opposite of hierarchy - a political context in which the actors centralize power and create superior and inferior sources of authority. Conceptually speaking, politics within a State are hierarchical, but politics among States are anarchical. ${ }^{8}$

International relations theories recognize that international relations transpire in a condition of anarchy. Generally speaking, this fact is not controversial. The controversies arise when theories explain the structure and dynamics of anarchy in international relations in different ways. The theories leave us with different perspectives on anarchy that share some features but diverge in critical ways, producing theoretical diversity that defies synthesis. All efforts to construct a grand, unifying theory have failed. The theory of open-source anarchy does not aim for this elusive synthesis. Rather, if credible, it will add to the diversity and the disagreement that already exists in this field of enquiry.

All leading international relations theories posit that anarchy affects the behavior of actors in the system. They differ on the extent of anarchy's effects on the actors' behavior and whether State or non-State intervention can alter anarchy's impact on such behavior. In general, the State-centric approaches of realism and institutionalism theorize anarchy as an exogenous, structural determinative of State behavior. In other words, anarchy structures and drives how States respond to other States. Anarchy does not fundamentally change under these theories, which means that the condition of anarchy generates similar patterns of predictable State behavior over time, regardless of the nature of the government controlling the States in the system or the level of non-State actor involvement in national or international politics.

7. Dunne \& Schmidt, supra note 3, at 143 ("By anarchy what is most often meant is that international politics takes place in an arena that has no overarching central authority above the individual collection of sovereign states.").

8. The real world is messier than analytical concepts because we sometimes see more anarchy in domestic politics, such as occurs in failed States, than witnessed in the relations between sovereign States, such as the member States of the European Union. 
For liberalism and constructivism, which acknowledge the participation and impact of non-State actors, anarchy reflects the preferences and ideas of actors in the system. Where realism and institutionalism start with anarchy to explain State behavior, liberalism and constructivism start with the behavior of non-State actors to explain why State behavior in anarchy looks and functions as it does. The anarchical structure of international politics does not, therefore, necessarily determine patterns of behavior for actors in the system. This approach allows analysis to take account of factors related to non-State actor participation that realism and institutionalism discount as irrelevant. Although they agree on the technical meaning of anarchy, the leading theories diverge significantly in their explanations of anarchy's conceptual and practical meaning in international relations.

\section{B. What is "Open-Source Anarchy"?}

The concept of "open-source anarchy" attempts to communicate that the leading theories of international relations described above do not adequately explain the condition of anarchy in international relations in the early twenty-first century. The concept borrows from the open-source software movement, which involves people accessing, modifying, and disseminating software source code in an effort to make the software operate better. ${ }^{9}$ The analogy is not comprehensive because, as analyzed later in the paper, aspects of open-source anarchy do not necessarily produce iteratively better international relations. The key part of the analogy is the "open source" idea. The theory of open-source anarchy posits that anarchy, as the defining feature of international relations, has become directly accessible to non-State actors as never before. ${ }^{10}$ This direct access has features and consequences for world politics that none of the leading theories of international relations explain well.

At first glance, the reason why realism and institutionalism do not explain open-source anarchy is clear from their analytical premise that only States are key actors in international politics. This article probes this premise in more detail later, but, for the moment, the growing interest in non-State actor involvement in

9. For more on the open-source software movement, see generally Steve Weber, The Success of Open Source (2004); Open Source Initiative, http://www.opensource.org/ (open source is a development method of software that harnesses the power of distributed peer review and transparency of the process).

10. The theory of open-source anarchy also relates to the phenomenon of small, weak States, such as failed States, having more impact on international relations than in past historical periods, but this article focuses on the relationship between non-State actors and open-source anarchy. 
international politics through globalization becomes increasingly difficult for realism and institutionalism to ignore." These State-centric theories, which emphasize rational State calculations concerning their power and material capabilities, cannot explain the violent, destabilizing threats posed by global terrorist groups or global organized crime syndicates to State interests and stability without forcing these threats into traditional patterns of State-centric rivalries (e.g., terrorism is State-sponsored and merely another weapon in the competition among States for power and influence). Changing the facts to fit the theory is not, however, an impressive analytical move. Similarly, realism and institutionalism struggle to explain why powerful States, such as the United States, have to concern themselves with weak, failing States that become platforms for malevolent non-State actors to threaten the interests of the powerful States.

Liberalism's and constructivism's openness to the role and influence of nonState actors may suggest that open-source anarchy is just a fancy way of capturing what these theories already acknowledge. Differentiating open-source anarchy from these two theories requires more effort, and the article undertakes this work below. In brief, even though liberalism and constructivism recognize non-State actors as participants in anarchical politics, the reality of non-State actor behavior in international relations does not often conform to the way these theories conceptualize such actors' involvement. Identifying a role for non-State actors in world affairs is not the same thing as explaining the way such actors actually participate in such affairs or the actual impact they have on the dynamics of international politics. The theory of open-source anarchy attempts to capture those aspects of non-State actor participation not adequately addressed by liberalism and constructivism.

\section{Perspectives on Anarchy in International Relations Theory}

\section{A. State-Centric Theories and the Westphalian Source Code for Anarchy}

As is well known, realism and institutionalism focus analysis on States and their interactions. The dominant role of States in international relations forms a key assumption for these theories. The consequences for understanding anarchy of this State-centric or Westphalian approach are familiar and need not be described again here. The State-centric approach has, however, another consequence that realism and institutionalism typically do not illuminate. By privileging States,

11. See, e.g., Drezner, supra note 1, at 209 (arguing that "[s]tructural realists . . have tended to ignore or trivialize globalization's salience."). 
and excluding non-State actors as independent factors, realism and institutionalism deliberately make anarchy a closed system, accessible only to States.

To make another software analogy, realism and institutionalism reveal anarchy operating under a proprietary source code for international relations that only States develop, access, and use. This analogy means that anarchy is not a natural law of international relations but is deliberately designed to make international politics a closed system, off limits to non-State actors attempting to influence events independent of States. In contemporary times, we tend to consider the Westphalian system as anachronistic, which obscures the innovation this system represented when established in the seventeenth century. The Westphalian structure emerged from the horrific Thirty Years' War (1618-1648) as a way to prevent countries from devastating each other through religious wars. The State system attempted to seal itself off from the violence and instability transnational sectarianism could unleash among nations. In short, the Westphalian structure embodied a conservative ethos wary of the danger that ideas and transnational zealotry can create within the system of States. ${ }^{12}$

The State-centric, proprietary source code of Westphalian anarchy can be found partly in the development of the modern system of international law, especially its principle of territorial sovereignty, the principle of non-intervention in domestic affairs of other States, and its grounding of the binding nature of international legal obligations in State consent. As natural law faded as an influence on international law, States became the sole subjects and authors of international law. International law became, literally, whatever States wanted it to be. Awkward situations created by the behavior of non-State actors, such as merchants engaging in economic activities in foreign countries and pirates, were brought back within the State system through the international legal principles of diplomatic protection for nationals overseas and universal jurisdiction over piracy.

The Westphalian source code for anarchy extended beyond international law and included, importantly, the balance of power. The utilization of the balance of power as a governance mechanism in international politics highlighted the significance of the great powers, the importance of monitoring their competition, the critical role of war in making the balance of power function, and the need for national military strength. The dynamics of balance of power politics encouraged

12. The shared political, economic, cultural, and religious heritage of the European States that created the Westphalian system gave this conservative ethos a fairly solid foundation. See Antonio Cassese, International Law in a Divided World 38-39 (1986) (describing the common background of the States that created the Westphalian system). 
the development of ever more politically, economically, and militarily powerful States, reducing the likelihood that non-State actors could significantly affect anarchy and its politics without the imprimatur of the great powers. The dynamics of the balance of power also made it very unlikely that any one State or group of States could force a radical change in the Westphalian source code, or, as Vattel put it, the balance of power is "a state of affairs such that no one power is in a position where it is preponderant and can lay down the law to others." ${ }^{\text {"3 }}$

These observations link to the emphasis that realism and institutionalism. place on State power and material capabilities in anarchy, and, with the rise of the modern, territorial State, the only entities with power and material capabilities large enough to survive in, and materially affect, anarchical politics were States. The industrial revolution in the nineteenth century accelerated the advantages States had over other actors in terms of material power, especially military capabilities. The development of the modern State system after the Peace of Westphalia in 1648 exponentially raised the material barriers to entry for non-State actors into the game of international politics.

What States feared were not non-State actors but religious or ideological forces that could trigger conflict among powerful States. The Westphalian system emerged from the religious fratricide of the Thirty Years' War, and the French Revolution and its bloody Napoloenic aftermath shook the system violently again. The seriousness with which some States took the systemic threat of transnational ideologies is revealed in the post-Napoleonic attempt by the Holy Alliance of great powers (Russia, Austria, and Prussia) to implement a principle of intervention into the domestic affairs of States against forces seeking to overthrow existing governments and, as a result, destabilize the international system.

The Westphalian source code for anarchy also viewed economic activity undertaken by private actors through State-centric lenses. As suggested by the policy of mercantilism, States calculated economic development and trade as elements of national power, translating what non-State actors generated in their domestic and transnational economic activities into resources relevant to the competition States endured in international politics. Similarly, States strategically outsourced aspects of power politics by employing ostensibly private enterprises (e.g., the East India Company) to expand State influence and power overseas and provide footholds for the empire.

Realism and institutionalism recognize that the Westphalian source code for anarchy was created and is not the result of some primordial, unknowable force.

13. Hedley Bull, The Anarchical Society 101 (1977). 
These theories have elucidated features of this source code's functioning, especially the powerful, relentless, and often grim logic of inter-State competition (e.g., the security dilemma ${ }^{14}$ ) that it fosters. Institutionalism has tinkered with the source code by focusing on how formal and informal international institutions or regimes can mitigate the harshness of State competition in some (but not all) areas of international relations. Realists do not deny the existence of international institutions or regimes; they reject that these attempts at mutually expedient cooperation have any independent effect on State calculations of power and interest in the condition of anarchy in which States interact.

The disagreements between realism and institutionalism do not obscure, however, their common position that the condition of anarchy remains, essentially, the exclusive province of States. The Westphalian source code for anarchy was written by States for the interest of States, irrespective of their internal form of government, ideological predilections, cultural mores, and religious traditions-none of which materially alters how the source code functions. At a deeper level, realism and institutionalism cast doubts on whether States can alter the source code much, even if they wished to do so, absent some cataclysmic event that shatters, temporarily, the balance of power (e.g., the French Revolution and the rise of Napoleonic France). The Westphalian source code self-perpetuates because the logic of anarchical relations, with the premium it places on State material capabilities and power, reinforces the code regardless of the kind of "hardware" (i.e., States) that runs it.

\section{B. Pluralistic Theories and Alternative Perspectives on Anarchy}

Although influential, the State-centric theories of international relations do not monopolize the field. Other theories have developed approaches that accord non-State actors roles in the way anarchy operates. These pluralistic theories read anarchy differently, both in terms of how it operates and what might be possible within it. By expanding the cast of actors, the pluralistic perspectives break open the closed, proprietary nature of anarchy stressed by State-centric theories. Pluralistic theories generally attempt to push new ideas through the cracks they create in the Westphalian shell in order to transform how anarchy functions.

Theoretical disagreement with the Westphalian model of international relations emerged in the thinking of some of the world's greatest philosophers, in-

14. See, e.g., Robert Jervis, Cooperation Under the Security Dilemma, 30 World Pol. 167 (1978). 
cluding Jean-Jacques Rousseau, ${ }^{15}$ Immanuel Kant, ${ }^{16}$ Edmund Burke, ${ }^{17}$ and Karl Marx. ${ }^{18}$ What is striking about the thinking of these men is how they integrate analysis of international relations and domestic politics. The Westphalian source code for anarchical politics separates international relations from the domestic realm and from transnational politics among non-State actors. Analytically, the State-centric theories hermetically seal international relations from other forms of political thought and action. Rousseau, Kant, Burke, and Marx integrate ideas across the domestic-international divide, often drawing attention to the importance of transnational phenomena, such as commerce, culture, and class. This approach makes their thinking sensitive to the influence of non-State actors within and among States.

Some examples from Marx and Kant illustrate these observations. Marx's thinking was perhaps the most radical in challenging Westphalian wisdom because he subordinated the State and inter-State relations to the transnational behavior of the capitalist class. ${ }^{19}$ International relations were merely another venue for the struggle for control of the means of production between the bourgeois and the proletariat classes. Kant's radicalism did not subordinate the State as Marx's did; rather, Kant sought to change international politics fundamentally by transforming the nature of the State (e.g., all States shall be constitutional republics) and the nature of inter-

15. On Rousseau's thinking on international relations, see generally Francis H. Hinsley, Power and the Pursuit of Peace: Theory and Practice in the History of Relations 46-61 (1963); Rousseau on International Relations (Stanley Hoffmann \& David P. Fidler eds., 1991); David P. Fidler, Desperately Clinging to Grotian and Kantian Sheep: Rousseau's Attempted Escape from the State of War, in Classical Theories of International Relations 120 (Ian Clark \& Iver B. Neumann eds., 1996).

16. On Kant's thinking on international relations, see generally Hissley, supra note 15 , at 62-80; Howard Williams \& Ken Booth, Kant: Theorist Without Limits, in Classical Theories of InTERnational Relations, supra note 15 , at 71.

17. On Burke's thinking on international relations, see generally EMPiRE and Community: Edmund Burke's Writings and Speeches on International Relations (David. P. Fidler \& Jennifer M. Welsh eds., 1999); Jennifer M. Welsh, Edmund Burke and International Relations: The Commonwealth of Europe and the Crusade Against the French Revolution (1995); Robert J. Vincent, Edmund Burke and the Theory of Intermational Relations, 10 Rev. InT'L Stud. 206 (1984).

18. On Marx's thinking on international relations, see generally V. Kubalkova \& A. Cruickshank, Marxism and International Relations (1985); Andrew Linklater, Marxism, in Theories of International Relations 119 (Scott Burchill \& Andrew Linklater eds., 1996).

19. See, e.g., Karl Marx \& Friedrick Engels, The Communist Manifesto, reprinted in Essential Works of Marxism 13 (Arthur. P. Mendel ed., 1961) ("The history of all hitherto existing society is the history of class struggles."). 
State relations (e.g., the prospect of perpetual peace). ${ }^{20}$ To achieve these ends, Kant's strategy relied on non-State actors as the change agents for world affairs.

In academic international relations theory, the leading pluralistic theories are liberalism and constructivism, which recognize States and non-State actors as important influences in international relations. Therefore, neither liberalism nor constructivism interprets anarchy as a closed, proprietary system monopolized by States and dominated by the great powers. States remain important players under both theories, but these theories explain how States and non-State actors relate to anarchy in ways radically different from realism and institurionalism.

Realism and institutionalism explain the similarity of State interests and actions over time by stressing the logic of anarchy. Liberalism accepts that international relations occur in a condition of anarchy, but it tries to explain why State interests and behavior differ when all States face the same structural environment of anarchy. In other words, liberalism denies that States invariably adopt the Westphalian source code for anarchical politics. The reason for variance in State behavior, even under conditions of anarchy, relates to the formation of political preferences by non-State actors and how those actors get their preferences expressed through domestic processes as State policy in international relations. NonState actors achieve this impact on State policy through domestic politics (e.g., elections, lobbying) and transnational activities (e.g., trade, civil society activism), both of which shape the content of State policy preferences in international relations, which in turn determines the nature of anarchy prevailing among States. ${ }^{21}$

Under liberalism, non-State actors participate, through States, in writing the source code for anarchy. Liberalism creates the possibility that States could write different source codes for anarchy based on configurations of non-State actor preferences. This possibility is why liberal theorists argue that liberalism explains variation in the content of different States' foreign policies and change in the dynamics of the international system over time. Although liberalism opens international relations to the influence of non-State actors, it filters the impact of this participation through the State. Non-State actors, in essence, access anarchy indirectly through the State. To understand how States write source codes for anarchy

20. Immanuel Kant, Perpetual Peace: A Philosophical Sketch (1795), available at http://www.mt holyoke.edu/acad/intrel/kant/kantl.htm.

21. See, e.g., Drezner, supra note 1 , at 6 (describing this dynamic as a two-step approach to international relations theory: "The first step is identifying the domestic actors and institutions that explain the origin of state preferences. The second step is to take those preferences as given for international interactions, and to explain the bargaining outcomes as a function of the distribution of interests and capabilities."). 
requires understanding how the formation and expression of non-State actor preferences shape States' policies. We have not reached the central idea of opensource anarchy, which is how the direct involvement of non-State actors in international relations affects the nature of anarchy.

Constructivism, like liberalism, interprets international relations in ways that indicate potential roles for non-State actors. For constructivists, "anarchy" is a socially constructed idea, and, as such, it has no fixed, unchanging meaning. Our understanding of anarchy forms through inter-subjective processes in which actors (both State and non-State) construct, deconstruct, and reconstruct the meaning of ideas. In these processes, agents (e.g., States, non-State actors) build structures (e.g., rules, institutions), and the building process is dynamic because through it, the interests and identities of the agents can be redefined. These redefinitions feed into how the structures operate and perhaps get modified, and the constitutive feedback loop begins again.

Of the four theories described in this article, constructivism appears to be the most accommodating to the notion that non-State actors can directly affect the nature of anarchy. The impact of non-State actors in the formation of global norms, for example, becomes part of how these norms affect the interests and identities of other agents, be they States or other non-State actors. For constructivists, anarchy is what States and non-State actors make of it. For constructivists, ideational ebb and flow, not material power and capabilities, determines the nature of anarchy. From the constructivist perspective, anarchy is perpetually malleable because its content is never permanently fixed, and constitutive inputs that transform the status quo can emerge from the interactions of States or non-State actors at any time.

In addition, the constitutive role of non-State actors can be independent of the processes through which domestic preference formations influence the policies of States. In other words, non-State actors can independently affect anarchy through direct transnational activities without requiring the filter of the State as an intervening factor. As the number of non-State actors engaging in transnational activities increases, and as the intensity and scope of their activities expands, their potential role in the social construction of international relations increases.

Constructivism provides a way to see how non-State actors can independently and directly affect the structure and dynamics of anarchy. But constructivism is not the theory of open-source anarchy for purposes of this article. Even though constructivism provides the possibility for non-State actors to affect international relations independently of States, leading constructivists remain focused on explaining how States socially construct their interests, identities, and interactions. 
Why constructivism privileges States theoretically is not entirely clear given that the "State" is, under constructivist assumptions, simply a socially constructed notion without any a priori claim to special status in political life. The reason why States remain privileged actors in constructivism relates to their abilities to wield greater material power in anarchy than non-State actors, which is the main point of departure for realism and institutionalism.

For constructivism, however, the role of non-State actors in processes of social construction is ideational, not material, because non-State actors seek to translate ideas into alternative interests, identities, and interactions concerning inter-State relations. Unlike realism and institutionalism, where theory follows practice, constructivism holds that ideas determine behavior in the real world. The non-State actors influence the processes of social construction for purposes of forming the State's perception of itself and the world it inhabits. Generally speaking, constructivism's anti-materialistic approach means that it does not scrutinize whether non-State actors themselves may be gaining material power and capabilities to affect anarchy directly in unprecedented ways.

What none of the four leading theories of international relations addresses is how the exercise of material power by non-State actors may affect the structure and dynamics of anarchy, including the role that ideas might play. Realism and institutionalism stress the critical theoretical role of material capabilities, but only when States possess such capabilities. The possibility that non-State actors could have anarchy-affecting material power never arises in realism and institutionalism. Theories that open analytical space for examining non-State actors in international relations stress how these actors affect the world of ideas, interests, preferences, and identities, but they do not reflect on the consequences of nonState actors wielding material power against States or each other.

The theory of open-source anarchy seeks to explain how and why non-State actors have grown in material power and what consequences for anarchy flow from this development in international relations. The next part of this article attempts to provide this explanation.

\section{Open-Source Anarchy: Theoretical Considerations}

\section{A. The Westphalian Source Code and Oligopolistic Anarchy}

The proposition requiring theoretical support is that non-State actors play a larger role in international relations than in earlier historical periods. This larger 
role involves both heightened participation in processes that determine the nature of anarchy and increased impact on the outcomes these processes yield. Anarchy, in its technical sense, was present in those earlier times and continues to characterize international relations today. The argument is that something has changed in how anarchy functions that allows non-State actors to have more presence and influence in international relations. Theoretically, how do we support this argument and explain this change?

To return to the software analogy for a moment, the open-source software movement challenges the perceived market dominançe of proprietary software. To mount such a challenge, the open-source software movement required, first, software source code to manipulate, and second, enabling capabilities to allow many others to access, use, improve, and redisseminate the modified source code. Without non-proprietary source code and low-cost enabling capabilities, open-source software faced significant barriers to entry in challenging proprietary software's market dominance. In other words, without non-proprietary source code and ways to share it cheaply and widely, open-source software engineers would have to incur high transaction costs to develop and disseminate open-source software that only reaches a small number of like-minded individuals. In such a situation, open-source software would have been more of an eccentric hobby than a global movement.

What really made the open-source software movement possible was the Internet. The Internet enabled non-proprietary software to be shared and iteratively improved widely and cheaply. With the Internet, barriers to entry for competing head-to-head with proprietary software fell significantly, allowing open-source software to make inroads against proprietary software companies. The counter-corporate idea of opensource software has gained significant attention, but we should not forget that the buzz about this idea depends on the existence of a material capability that makes the idea viable. For whatever else the Internet means in the open-source software movement, it is foremost a material capability for the movement, not an idea. It provides a material means to allow packets of digital data to be distributed, accessed, utilized, manipulated, and redisseminated rapidly, widely, and economically. The material capability provided by the Internet allows the packets of ideas associated with the open-source software movement to advance this philosophy of software development and gain more adherents to the movement.

Returning to the problem of anarchy in international relations, recall my earlier references to the closed Westphalian source code for international relations that was "proprietary" to States, and particularly the great powers. Emergence of open-source anarchy implies that control over the "source code" for anarchy is no 
longer the exclusive domain of States and the acknowledged prerogative of the great powers. This change implies that the ideas and material capabilities of nonState actors provide them with direct access to influence how anarchy operates. This access involves both increased participation in, and impact on, the writing and implementation of the source code for anarchy.

To try to understand this purported transformation, we can think of anarchy as a kind of market for power and ideas. Different market structures produce different relationships between power and ideas. The State-centric, Westphalian approach to anarchy resembles an oligopolistic market in which a small number of great powers determine supply and demand for power and ideas in anarchy. Great powers dominate in oligopolistic anarchy because they have achieved economies of scale in the production and use of material capabilities, particularly military power, that render them relatively invulnerable to competition from weaker States and non-State actors.

As realism and institutionalism argue, competition among the great powers focuses on material power, and this form of competition stifles the impact of ideational and normative innovations because States filter everything through the prism of the balance of material power. Through this process' relentless focus on power, battles over ideas and ideologies become thinly disguised components of the larger competition for power among States. This observation brings to mind the famous Melian Dialogue from Thucydides, in which the Athenians counsel the Melians to dispense with ideas and rhetoric about allies, justice, and hope and to calculate on the basis of material interest and power. ${ }^{22}$ Similarly, States filtered their concerns about transnational religious sectarianism (e.g., Thirty Years' War) or revolutionary ideologies (e.g., French Revolution, Bolshevik Revolution) through the political filter of the balance of power, which operates to oppose sudden, violent changes to the system. This line of reasoning connects to E. H. Carr's classic description of the relativity of ideas in the world of international relations: "The realist has thus been enabled to demonstrate that the intellectual theories and ethical standards of utopianism, far from being the expression of absolute and a priori principles, are historically conditioned, being both products of circumstances and interests and weapons framed for the furtherance of interests." ${ }^{23}$

Put another way, the relationship between power and ideas in oligopolistic anarchy is inelastic. Changes with respect to ideas have little to no sustained impact on either the configuration of power among States or how States configure

22. Thucydides, History of the Peloponnesian War 400-08 (Rex Warner trans., 1954).

23. CARR, supra note 3 , at 68 . 
their approaches to their interests or power. The great powers have such advantages in terms of material capabilities that weaker States and non-State actors face formidable barriers to influencing the structure and dynamics of anarchy. Idea formation and normative activism does not cease, but it has little to no impact on the machinations of the great powers in oligopolistic anarchy. As suggested by realism and institutionalism, whatever impact ideational ferment has remains primarily a topic for the study of domestic politics and does not constitute an independent variable affecting the outcome of international politics. "

\section{B. Open-Source Anarchy and Elasticity in the Relationship between Power and Ideas}

To change oligopolistic anarchy to allow non-State actors to affect anarchy directly requires significantly altering the material conditions of competition among the actors. These alterations cannot be changes that merely agitate great power competition for security and influence (e.g., the development of new military technologies) because such changes would simply reinforce the inelastic relationship between power and ideas present in oligopolistic anarchy. The sharper the struggle for material power among States becomes, the less room ideas promulgated by State or non-State actors have for influencing State behavior in anarchy. Moving from an inelastic to a more elastic relationship between power and ideas in anarchy requires (1) greatly reduced competition among States for power (e.g., the emergence of a hegemon through degradation in the material capabilities of other great powers); and/or (2) transformations that allow non-State actors to develop greater material capabilities in world affairs.

The perceived increase in the role of non-State actors in international relations over the past two decades coincides with (1) the emergence of the United States as the preponderant power after the collapse of the Soviet Union; and (2) technological developments concerning the means of transportation, production, weaponization, and communication that have allowed non-State actors (e.g., terrorist groups, transnational organized crime, corporations, and non-governmental organizations (NGOs)) to increase their material capabilities for engaging in world affairs. The dramatic change in the structure of competition for material power among States, combined with the diffusion of material capabilities to nonState actors through technological transformations, opened the condition of anarchy to more direct and independent access by various non-State actors. Through this access, non-State actors have more impact on how anarchy functions.

The development of open-source anarchy is, therefore, a function of structural 
and technological changes that significantly lowered the barriers to entry for nonState actors to access and affect directly and independently the condition of anarchy that characterizes international relations. These changes also made the relationship between power and ideas more elastic. In other words, changes in material capabilities of State and non-State actors have a more significant effect on the world of ideas in open-source anarchy, and vice versa, than prevailed in Westphalian anarchy.

Some examples help illustrate the reasoning behind this argument. Ideational and normative ferment usually follows significant structural changes in the balance of material power in international relations. The end of the Napoleonic Wars produced (1) the Holy Alliance, with its emphasis on preventing revolutions from destabilizing the international system; and (2) the Congress System, which, according to Hinsley, "was essentially the first attempt in history ... consciously to find an alternative both to the old aim of domination by one Power ... and to the balance of power as it had operated in the eighteenth century, from which all felt it imperative to escape."24 Similarly, the end of catastrophic World War I, which shattered key great powers and their empires, led to an array of new ideational directions, ranging from making the world safe for democracy to the League of Nations experiment. The aftermath of World War II produced the United Nations (U.N.), new international economic and financial architecture (i.e., the Bretton Woods system), and the launch of the human rights movement.

An explosion of normative activity also occurred after the Cold War and the termination of its rigid, bipolar competition between the United States and the Soviet Union. We saw the major expansion of the liberal international trading system in the form of the World Trade Organization (WTO), new paradigms for humanitarian intervention (e.g., the responsibility to protect), the reinvigoration of notions of collective security through U.N. Security Council action, the emergence of new concepts such as human security, emphasis on democracy as a fundamental human right, the implementation of new strategies for development (e.g., the Millennium Development Goals), experimentation with new forms of global governance (e.g., public-private partnerships), the spread of civil society activism globally, and the realization of long-stultified normative visions, such as the International Criminal Court.

Criticism that many of the normative changes that occurred after the end of the Cold War reflect preferences of the new predominant power, the United States, does not diminish the importance of the elasticity between power and ideas that developed in this period. As the dominant power facing no serious existential

24. Hinsley, supra note 15, at 196. 
threats, the United States did not have to scrutinize each and every normative innovation or movement for threats to its material power, security, and survival. In addition, because the United States is a democracy, non-State actors of all sorts energetically sought to sway U.S. preferences in international relations towards new strategies, concepts, and visions. The result was extraordinary ideational ferment occurring inside and outside the halls of power of the world's strongest country. The disintegration of the Soviet Union left U.S. forteign policy in need of new concepts, strategies, and tactics. Ironically, a quasi-hegemonic power structure greatly increased the elasticity between power and ideas in international relations and the opportunities for non-State actors to influence world affairs.

An illuminating example of this new elasticity comes from the treatment of the HIV/AIDS pandemic before and after the end of the Cold War. In 1987, the Central Intelligence Agency (CIA) produced a report on the growing problem of HIV/ AIDS in Africa that contained predictions that are chilling to read twenty years later, when HIV/AIDS has developed into one of history's worst pandemics. ${ }^{25}$ The CIA's 1987 report emphasized, however, what consequences the spread of HIV/ AIDS would have on the U.S.-Soviet rivalry. ${ }^{26}$ Despite the staggering estimates in the 1987 CIA report of the toll HIV/AIDS could wreak, ${ }^{27}$ the impact of this problem on the U.S.-Soviet competition was marginal compared to the dramatic changes in Soviet policy already becoming apparent in 1987 under Mikhail Gorbachev.

The HIV/AIDS pandemic continued to grow after the end of the Cold War, and, in the latter half of the 1990s, the U.S. government became increasingly concerned about this problem and began to think about it (not always coherently) across a range of interests, including national security, trade policy, development strategies, and human rights. How HIV/AIDS was manifesting itself in U.S.

25. Central Intelligence Agency, SNIE 70/1-87, Sub-Saharan A frica: Implications of the AIDS PANDEMIC (1987).

26. Id. at 6 ("The United States and other Western countries will probably be asked to increase greatly their assistance to Africa. A refusal to divert or create new development funds to take on the enormous costs of upgrading health infrastructures will open the door to harsh criticism by beleaguered African countries. The Soviets will probably step up their anti-US disinformation campaign in the wake of an African backlash, and the United States will continue to need a vigorous counter to such propaganda. Renewed Soviet accusations that US military personnel spread AIDS could lead to more troublesome and contentious negotiations for military basing agreements and other military activities.") (emphasis in original). See also id. at 17 (Annex on Soviet AIDS Disinformation Campaign).

27. Id. at 4-5 ("The long-range impact of AIDS will be devastating. Heavily infected countries will suffer irreplaceable population losses in those groups most essential to their future development: midlevel economic and political managers, agrarian and urban workers, and military personnel.") (emphasis in original). 
policy reflected the new elasticity between power and ideas triggered by the collapse of the bipolar balance of power system. This elasticity continued to appear in further developments on HIV/AIDS, including discussion of this problem before the Security Council, the targeting of HIV/AIDS in the Millennium Development Goals, the establishment of the Global Fund to Fights AIDS, Tuberculosis, and Malaria, and the controversies on developing-country access to patented antiretroviral treatments in the context of the WTO's Agreement on Trade-Related Aspects of Intellectual Property Rights. All this activity across so many areas of U.S. foreign policy stands in stark contrast to how the CIA in 1987 coldly calculated the significance of this growing human catastrophe through the prism of the balance of power with the Soviet Union.

The end of the Cold War also brought changes in terms of the material capabilities of non-State actors. The globalization of production processes, capital mobility, financial services, and communication technologies gave corporations, for example, greater influence over a wider range of political and economic affairs than anything seen during the Cold War. This perceived influence of transnational corporations became a target of NGOs concerned about corporations exploiting workers and communities through the exercise of unaccountable political and economic power. In response, NGOs sharpened their abilities to counter what they perceived as corporate abuses of labor standards, human rights, and principles of environmental protection, often trying to shame corporations morally through advocacy and hit them in the pocketbook through boycotts and litigation. Thus, even as between quarreling non-State actors, we see elasticity between ideas and power not present before the end of the Cold War.

As globalization accelerated in the wake of the radical transformation in the structure of the balance of power, States became increasingly concerned that nonState actors-whether terrorist groups, transnational organized crime, corporations, or NGOs-could exercise their growing material capabilities in ways harmful, dangerous, or threatening to State interests. Some States and NGOs fretted that the power of multinational corporations was causing a "race to the bottom" in terms of domestic regulatory standards. The growing global activism of NGOs produced concerns about these new "global potentates" 28 and their unaccountable influence. More malevolently, terrorist groups and global crime syndicates began to exploit globalization's commercial, financial, transportation, weapons, and communication pathways and technologies coming on-stream all over the world.

28. See Peter Spiro, New Global Potentates? Nongovernmental Organizations and the "Unregulated" Marketplace, 18 Cardozo L. Rev. 957 (1996). 
Although some of these concerns have proven exaggerated, the common theme of the growth in the material capabilities of non-State actors to engage in a broader range of activities more rapidly and globally remains valid. The impact of this growth in material capabilities on anarchical politics is not uniform across non-State actors. On the one hand, for some NGOs, global communication technologies have allowed them to increase their participation in diplomatic and governance processes and the "noise" they can gerierate about issues, but increased participation and louder voice does not necessarily translate into impact on the outcome of decisions States make in international relations. On the other hand, for some terrorist groups ánd global criminal enterprises, globalization's processes have allowed them to grow in material power and to inflict serious political and economic costs on States, even the purported hegemon.

No better example of the growth and use of material power by a non-State actor can be found than Al-Qaeda. This terrorist group's repeated attacks against the United States starting in the latter half of the 1990s, on September 11th, and in Afghanistan and Iraq have dramatically affected U.S. national security and foreign policies at every level of government. Al-Qaeda's success in hurting the United States repeatedly in its homeland and in multiple foreign countries has no equivalent for any great power in any previous period in the history of the modern States system. Al-Qaeda has accessed anarchy and influenced its dynamics in ways that many States could never imagine accomplishing.

In addition, the example of Al-Qaeda also illustrates the elasticity of power and ideas in open-source anarchy. Al-Qaeda's attacks on the United States, and U.S. responses to the Al-Qaeda threat, have bolstered the legitimacy of Al-Qaeda's normative agenda as a radical Islamist group in the eyes of many Muslims. The extent to which radical Islamist groups and individuals use the Internet to foster solidarity and spread their beliefs globally makes this combination more formidable as a material threat and as a source of anti-Western ideas. ${ }^{29}$ David Kilcullen has written that "[o]ne of the most significant 'globalization effects' is the rise of a worldwide audience, giving insurgents near-instantenous means to publicize their cause. Globalized internet communication also enables moral, financial and personnel support, creating a strategic hinterland or 'virtual sanctuary' for insurgents." 30

29. See, e.g., Internet Jihad: $A$ World Wide Web of Terror, ThE Economist, July 14, 2007, at 28 (describing growth of the use of the Internet by Al-Qaeda and other Islamist extremists).

30. David Kilcullen, Counterinsurgency Redux, Small Wars Journal (2006), available at http:// www.smallwarsjournal.com/documents/kilcullenl.pdf. 
The odd phenomenon of reactionary and violent Islamist ideologues exploiting the Internet, perhaps the most powerful instrument of globalization, provides a potent example of how the elasticity between power and ideas in open-source anarchy can be dangerous, even for the world's most powerful State. Joseph Stalin once famously mocked the international influence of the Roman Catholic Church by asking how many divisions the pope had. Today, the United States is deeply worried about how many jihadists surf the Internet. The scale of the use of the Internet by radical Islamists has narrowed the traditional gap between "hard power" and "soft power" in the new environment of open-source anarchy. The harnessing of globalization's material tools by the ideology of radical Islamists has caused commentators to warn that the United States faces an increasingly potent global insurgency movement it is ill prepared to counter. ${ }^{31}$

The elasticity between power and ideas in open-source anarchy has also had negative "blowback" for the United States as it has tried to address the global terrorist threat. In the eyes of many, U.S. efforts to use primarily its formidable military power against Al-Qaeda and other terrorist groups has simultaneously failed to achieve sustained material degradation of the threat and tarnished the legitimacy of the U.S. normative agenda in this struggle. Not only has Al-Qaeda defied U.S. military might but it has benefited from the parade of ideational disasters the United States has brought upon itself: the evaporation of the rationales given for invading Iraq, the incompetence of the occupation of Iraq, the continued failure to secure Afghanistan, and the pursuit of interrogation and detention policies that have led to torture, abuse, and questions about American commitment to the rule of law. The elasticity of power and ideas in open-source anarchy has cost the United States dearly in its attempts to address the global terrorist threat.

31. Audrey Kurth Cronin, Cyber-Mobilization: The New Levée en Masse, Parameters, Summer 2006, at 77:

The means and ends of mass mobilization are changing, bypassing the traditional state-centered approach that was the hallmark of the French Revolution and leaving advanced Western democracies merely to react to the results. Today's dynamic social, economic, and political transitions are as important to war as were the changes at the end of the 18th century that Clausewitz observed. Most important is the 21st century's levée en masse, a mass networked mobilization that emerges from cyber-space with a direct impact on physical reality. Individually accessible, ordinary networked communications such as personal computers, DVDs, videotapes, and cell phones are altering the nature of human social interaction, thus also affecting the shape and outcome of domestic and international conflict. . . From the global spread of Islamist-inspired terrorist attacks, to the rapid evolution of insurgent tactics in Iraq, to the riots in France, and well beyond, the global, non-territorial nature of the information age is having a transformative effect on the broad evolution of conflict, and we are missing it. We are entering the cyber-mobilization era, but our current course consigns us merely to react to its effects. 
This elasticity also works dangerously with respect to global organized crime. The threat from this phenomenon is not a "clash of civilizations" as the global war on terrorism is sometimes considered because global criminal groups have no overarching "vision thing," like Osama Bin Laden's desire to reestablish an Islamic caliphate. However, these groups have sufficient material resources and means, and the viciousness to use them, that incantations about "law and order" from States are discredited unless they are backed up by effective law enforcement capabilities, cooperation, and action. The ability of global criminal elements to defy State authority enhances their power and makes them potential allies of other criminal gangs and terrorist groups, thus forming coalitions of non-State actors more prepared to challenge government authority and erode societal confidence in the government's ability to provide security and prosperity.

In open-source anarchy, the ability of non-State actors to affect international relations can also create opportunities for States to compete in more traditional ways. As the United States has experienced greater difficulties in fighting the global war on terrorism, especially in Afghanistan and Iraq, the emergence of open-source anarchy does not mean that States cease their competition with each other. Russia, China, India, North Korea, and Iran have all attempted to take advantage of the perceived weakening of U.S. power, influence, and credibility to enhance their respective positions.

How open-source anarchy affects State and non-State actor behavior and the outcome of international political cooperation or conflict is a complex question dependent on many variables. As noted earlier, open-source anarchy does not necessarily mean that non-State actors, or the ideas they promulgate, determine the nature of anarchy. Increased NGO participation in global governance processes is not the same thing as the capability to produce specific outcomes. Many non-State actor efforts to shape anarchy fail because of State indifference, opposition, or ability to shift negotiations to processes more conducive to achieving what States want. In addition, States have proved adept at exploiting or co-opting non-State actors in order to achieve their interests in international relations.

Acknowledging, however, that States, including the great powers, might have to fight violent transnational conflicts with non-State actors, expend material power to contain hostile non-State forces, bargain with or oppose non-State actors on how to address global problems, engage in high-profile normative jousting with non-State opponents, or shift negotiating forums to avoid difficulties presented by non-State actor participation and influence-all while keeping a wary eye on the machinations of rival States-means acknowledging that open-source 
anarchy is a real phenomenon. Grasping how open-source anarchy produces elasticity between material power and ideas in the interactions of all actors illuminates aspects of contemporary international relations not adequately explained by existing schools of international relations theory.

\section{Conclusion: Open-Source Anarchy and Governance of International Relations}

The impact of globalization on international relations has generated diverse theoretical attempts to explain what is happening, but the attempts have sparked more controversy than consensus. ${ }^{32}$ One source of dissatisfaction involves the sense that existing theories do not adequately capture how non-State actors affect, to varying degrees, how the condition of anarchy operates in international relations. State-centric theories, such as realism and institutionalism, do not recognize nonState actors as having any effect on the dynamics of anarchy and only understand those dynamics in terms of State calculations about material power. Theories that focus on non-State actors either filter non-State actor involvement through the State, as liberalism does, or argue that non-State actors affect anarchy through ideational and not material means, as constructivism does. We see non-State actors, however, wielding both material power and promulgating ideas independently from States in ways that have found increasing prominence in world affairs. This configuration of actors, power, and ideas does not fit well into any of the main schools of contemporary international relations theory. To try to explain this reality, this article constructed a theory of open-source anarchy.

At the heart of this approach rests the argument that anarchy functions like a market for power and ideas, which corresponds with a sense that international politics is not all about power, all about States, all about ideas, or all about nonState actors. What we need to understand is how power and ideas interact among the various State and non-State actors in the international condition of anarchy. The market metaphor permits exploration of different configurations of actors, power, and ideas in anarchy that can be tested against empirical evidence from the history of international relations. Thus, the Westphalian system can be conceptualized as an oligopolistic form of anarchy dominated by the great powers in which the relationship between material power and normative ideas is inelastic. In this type of anarchy, non-State actors have little, if any, impact on the way an-

32. See, e.g., Drezner, supra note 1 , at 3 ("Globalization is responsible for a lot of bad international relations theory."). 
archy functions primarily because of their lack of material capabilities to affect international politics.

Open-source anarchy posits an elastic relationship between power and ideas in which non-State actors directly participate, thus affecting, in various ways, how anarchy operates. This type of anarchy reflects changes in the distribution of material power among States and non-State actors that create more space for nonState actors to participate directly and indirectly in international relations. The proposition analyzed in this article is that the increased prominence of non-State actors in post-Cold War international relations flows from the combination of the end of the rigid, bipolar balance of power system of the Cold War and the technological and other transformations that allowed non-State actors to develop greater material capabilities for participating in world politics. As demonstrated, the postCold War period has experienced a more elastic relationship in international relations between material power and ideas, which is reflected in, and affected by, the participation and impact of non-State actors on the dynamics of anarchy.

This conceptual approach implies that open-source anarchy is not a permanent state of affairs for international relations. The market metaphor suggests that the market conditions for power and ideas can change, and the most significant driving factors for such change arise in connection with transformations in the material capabilities of the various actors. Open-source anarchy is a recent phenomenon, made possible by the combination of the structural transformation effected by the end of the Cold War and the contemporaneous convergence of technological transformations that increased non-State actors' material capabilities to engage in world affairs. Open-source anarchy may prove, however, to be ephemeral in the long run, especially if anarchy again becomes dominated by serious balance of power politics among the great powers.

For the short term, however, open-source anarchy looks fairly robust, but this reality creates problems for governing the condition of anarchy more effectively. The lowering of barriers to entry to non-State actors' participation in international affairs means that their number, diversity, and impact will continue to increase. As a result, we are likely to see more "unstructured plurality"33 in open-source anarchy as States and non-State actors access and try to influence the condition of anarchy. Concerns about unstructured plurality in world affairs have heightened interest in

33. On the problem of "unstructured plurality" in global governance, see generally C. L. R. Bartlett, et al., Cultural and Governance Influence on Detection, Identification and Monitoring of Human Disease, Foresight, 2006, http://www.foresight.gov.uk/Previous_Projects/Detection_and _Identification_of_Infectious_Diseases/Reports_and_Publications/Final_Reports/D/d4_3.pdf. 
building new governance "architecture" for international politics, ${ }^{34}$ but open-source anarchy proves a particularly bad environment in which to try to centralize, harmonize, and rationalize the behavior of States and non-State actors.

States, particularly the great powers, are notoriously reticent to consent to meaningful systems of international governance that crimp their sovereignty and freedom of action. Open-source anarchy does not significantly reduce this reticence, and may in some circumstances strengthen it. Further, the great powers have significant interests in preserving and exploiting unstructured plurality in global governance in order to find processes most conducive to satisfying their preferences. Opposition to new governance architecture may also appear in the self-interests of some non-State actors, such as corporations and NGOs, which value their increasing material capabilities that allow them to try to influence anarchy independently of States. Other non-State actors, namely terrorist groups and organized crime syndicates, will not, for obvious reasons, participate in constructing better ways to govern the unstructured plurality of open-source anarchy.

Another reason why open-source anarchy may not be conducive to more centralized, harmonized, and rationalized global governance architecture concerns the elasticity between power and ideas that this type of anarchy produces. This elasticity makes States and non-State actors highly sensitive to perceived changes in power relations and competition among ideas, perhaps heightening suspicions of the machinations behind proposals and fears of the consequences of significant change. Therefore, serious motivation to accept bold governance innovations may be lacking.

As suggested in the argument that radical Islamists constitute a global insurgency movement, the dynamics of open-source anarchy, particularly the elasticity between power and ideas, recalls principles of conducting counterinsurgency operations that stress the highly sensitive interdependencies between using military force and building political legitimacy. ${ }^{35}$ In other words, "winning the hearts and minds" in counterinsurgency only occurs if political and military authorities understand the elasticity that exists between power and ideas in the struggle with

34. On this phenomenon in the context of global health, see generally David P. Fidler, Architecture Amidst Anarchy: Global Health's Quest for Governance, 1 J. Global Health Governance 1 (January 2007), available at http://diplomacy.shu.edu/academics/global_health/journal/PDF/Fidler-article.pdf.

35. U.S. Army and Marine Corps, Counterinsurgency Field Manual 40 (2007) ("The political and military aspects of insurgencies are so bound together as to be inseparable... Military actions executed without properly assessing their political effects at best results in reduced effectiveness and at worst are counterproductive. Resolving most insurgencies requires a political solution; it is thus imperative that counterinsurgency actions do not hinder achieving that political solution."). 
insurgent forces. Although open-source anarchy encompasses more than counterinsurgency contexts, the analogy helps communicate how different open-source anarchy is from what prevailed during the Cold War and the periods before and between the world wars of the twentieth century. Operating effectively in this new kind of anarchy will prove daunting and dangerous for both State and nonState actors, but the stakes are certainly no less important than those faced in earlier, perhaps simpler, conditions of anarchy. 